\title{
Local circuits targeting parvalbumin-containing interneurons in layer IV of rat barrel cortex
}

\author{
Jochen F. Staiger • Werner Zuschratter • \\ Heiko J. Luhmann · Dirk Schubert
}

Received: 16 June 2009/Accepted: 12 October 2009/Published online: 31 October 2009

(C) The Author(s) 2009. This article is published with open access at Springerlink.com

\begin{abstract}
Interactions between inhibitory interneurons and excitatory spiny neurons and also other inhibitory cells represent fundamental network properties which cause the so-called thalamo-cortical response transformation and account for the well-known receptive field differences of cortical layer IV versus thalamic neurons. We investigated the currently largely unknown morphological basis of these interactions utilizing acute slice preparations of barrel cortex in P19-21 rats. Layer IV spiny (spiny stellate, star pyramidal and pyramidal) neurons or inhibitory (basket and bitufted) interneurons were electrophysiologically characterized and intracellularly biocytin-labeled. In the same slice, we stained parvalbumin-immunoreactive (PVir) interneurons as putative target cells after which the tissue was subjected to confocal image acquisition. Parallel experiments confirmed the existence of synaptic contacts in
\end{abstract}

Electronic supplementary material The online version of this article (doi:10.1007/s00429-009-0225-5) contains supplementary material, which is available to authorized users.

J. F. Staiger $(\bowtie)$

Department of Neuroanatomy, Institute of Anatomy

and Cell Biology, Albert-Ludwigs University Freiburg,

POB 111, 79001 Freiburg, Germany

e-mail: jochen.staiger@anat.uni-freiburg.de

W. Zuschratter

Leibniz Institute for Neurobiology, 39118 Magdeburg, Germany

H. J. Luhmann

Institute of Physiology and Pathophysiology,

University of Mainz, Duesbergweg 6, 55128 Mainz, Germany

D. Schubert

Donders Institute for Brain, Cognition and Behaviour,

Radboud University Nijmegen Medical Centre,

POB 9101, 6500 HB Nijmegen, The Netherlands these types of connection by correlated light and electron microscopy. The axons of the filled neurons differentially targeted barrel PV-ir interneurons: (1) The relative number of all contacted PV-ir cells within the axonal sphere was 5$17 \%$ for spiny $(n=10), 32$ and $58 \%$ for basket $(n=2)$ and 12 and $13 \%$ for bitufted $(n=2)$ cells. (2) The preferential subcellular site which was contacted on PV-ir target cells was somatic for four and dendritic for five spiny cells; for basket cells, there was a somatic and for bitufted cells a dendritic preference in each examined case. (3) The highest number of contacts on a single PV-ir cell was 9 (4 somatic and 5 dendritic) for spiny neurons, 15 (10 somatic and 5 dendritic) for basket cells and 4 (1 somatic and 3 dendritic) for bitufted cells. These patterns suggest a cell type-dependent communication within layer IV microcircuits in which PV-ir interneurons provide not only feedforward but also feedback inhibition thus triggering the thalamo-cortical response transformation.

Keywords Barrel cortex - Cortical circuitry · Inhibitory interneurons - Spiny neurons - Parvalbumin . Correlated light and electron microscopy

\section{Introduction}

In the primary somatosensory cortex, the granular layer IV receives the densest thalamic input from the so-called lemniscal system which is thought to carry specific tactile information to be processed by cortical circuits (Ahissar et al. 2000). Thus, layer IV is considered to be the main starting point of cortical information processing with a rich variety of either sequentially or parallely organized synaptic networks (Thomson and Bannister 2003; Lübke and Feldmeyer 2007; Schubert et al. 2007; Petersen 2007). 
These synaptic networks are embedded within and across a modular structure, called a cortical column (Mountcastle 1997). In a part of the rodent primary somatosensory cortex, a highly ordered array of clustered neurons has been found which process the afferent information of the facial whiskers on the snout (Woolsey and van der Loos 1970; Welker and Woolsey 1974). These neuronal clusters have been called barrels and it was subsequently shown that each of the barrels preferentially, though not exclusively, processes the tactile information derived from its corresponding whisker (Welker 1971; Simons 1978; Brecht and Sakmann 2002), and, in addition forms a morphological correlate of a functional column spanning through all cortical layers (Fox 2002; Staiger 2006). The spatial and temporal determinants of information processing are executed by principal (excitatory) neurons and governed by GABAergic (inhibitory) interneurons (Klausberger and Somogyi 2008).

Among the extremely heterogeneous GABAergic interneurons (Markram et al. 2004; Ascoli et al. 2008), the largest and best defined subclass contains the calciumbinding protein parvalbumin (Celio 1986; Ren et al. 1992). In rodent cortex these neurons are most numerous in layer IV, usually show a fast-spiking action potential firing pattern and display very frequently the morphology of multipolar basket cells (Kawaguchi and Kubota 1997; Karagiannis et al. 2009). Axo-axonic cells belonging to the population of fast-spiking parvalbumin-expressing cells have been found very rarely in previous studies (Kawaguchi 1995; Inda et al. 2009; Helmstaedter et al. 2009) and were absent from our sample. It has been postulated that the fast-spiking parvalbumin-containing cells are the major type for perisomatic inhibition in the cortex, thus powerfully controlling the incidence, pattern and timing of firing in excitatory pyramidal cells (Porter et al. 2001; Sun et al. 2006).

From a functional point of view it was often reported that layer IV acts as an inhibitory gate for incoming sensory information and that the basic mode of information processing in layer IV is inhibitory (Welker et al. 1993; Pinto et al. 2003). One correlate of this strong inhibitory influence is the so-called thalamo-cortical response transformation which has been described in several cortical areas and species (Simons and Carvell 1989; Winer et al. 2005; Hirsch and Martinez 2006). It captures the fact that the receptive field properties of neurons in the lemniscal thalamic nuclei are clearly different from their counterparts in layer IV, seemingly only one synapse further. The prevailing idea at the moment is that a convergent thalamic input effectively and quickly excites inhibitory interneurons in layer IV but less so the local excitatory spiny neurons (Porter et al. 2001; Swadlow 2003) which is also supported by previous anatomical data (Staiger et al. 1996).
Because of their intrinsic physiological features, fastspiking interneurons are capable of conferring a thalamusevoked feed-forward disynaptic inhibition on the otherwise monosynaptically excited spiny neurons (Sun et al. 2006; Inoue and Imoto 2006) as well as to participate in feedback inhibitory circuits (Beierlein et al. 2003). In vivo, this circuitry results in the need for a strong synchronized thalamic input on spiny neurons to escape this type of inhibition (Bruno and Sakmann 2006) which is capable of centering the receptive field more strictly to the corresponding space in the topographic map (Miller et al. 2001). In general, this may serve as a mechanism to segregate tactile information to allow a whisker-specific extraction of the physical features of external stimuli (Von Heimendahl et al. 2007).

Here, we present some evidence that parvalbumin-containing interneurons localized to whisker barrels are targeted by axonal collaterals of layer IV spiny neurons as well as by synapses of other local fast-spiking interneurons (basket cells) but much less frequently by regular-spiking non-pyramidal (bitufted) interneurons. This suggests that parvalbumin-immunoreactive (PV-ir) interneurons do participate not only in feed-forward but also in feedback inhibition and that strong homotypic synaptic interaction between these neurons is very likely to influence their ensemble activity as well.

\section{Materials and methods}

\section{Electrophysiology and slice processing}

All procedures were performed according to the German law on animal welfare which includes all adequate measures to minimize pain or discomfort. Male Wistar rats (postnatal day 19-21) from the local breeding facility of the Heinrich-Heine-University were used in the present study $(n=20)$. Animals were deeply anesthetized with Enflurane, decapitated and the brain was quickly removed. Coronal slices of $300 \mu \mathrm{m}$ or thalamo-cortical slices of $500 \mu \mathrm{m}$ thickness were prepared as previously described (Schubert et al. 2003; Staiger et al. 2004). Slices were placed in an interface- or submerged-type recording chamber, kept at $32 \pm 0.5^{\circ} \mathrm{C}$ and continuously superfused with artificial cerebrospinal fluid containing (in millimolar): $124 \mathrm{NaCl}, 1.25 \mathrm{NaH}_{2} \mathrm{PO}_{4}, 1.8 \mathrm{MgCl}_{2}, 1.6 \mathrm{CaCl}_{2}, 3$ $\mathrm{KCl}, 10$ Glucose, $26 \mathrm{NaHCO}_{3}$, saturated with carbogen $\left(95 \% \mathrm{O}_{2}\right.$ and $5 \% \mathrm{CO}_{2}$ ).

After at least an hour of equilibration, whole-cell current-clamp recordings in layer IV were performed. Electrodes were pulled from glass capillaries (GB 200 F8P, Science products, Hofheim, Germany) on a vertical microelectrode puller (PP-830, Narishige Tokyo, Japan) 
and had a final resistance of 5-7 M $\Omega$. The pipette solution contained (in millimolar): $130 \mathrm{~K}$-gluconate, $6 \mathrm{NaCl}$, $1 \mathrm{CaCl}_{2}, 2 \mathrm{MgCl}_{2}, 11$ EGTA, $10 \mathrm{~K}$-HEPES, $2 \mathrm{Na}_{2} \mathrm{ATP}$, $0.5 \mathrm{NaGTP}$. The $\mathrm{pH}$ was adjusted to 7.4 with $\mathrm{KOH}$. The osmolarity of the solution was $270 \mathrm{mOsm}$. Biocytin (10 mg/ml; Sigma, Taufkirchen, Germany) was added to the pipette solution. The patch pipettes were connected to a discontinuous voltage-clamp/current-clamp amplifier (SEC-05LX, npi, Tamm, Germany), typically operated in current-clamp mode. The signals were filtered at $3 \mathrm{kHz}$ and digitized using a LIH1600 (HEKA Elektronik, Lambrecht, Germany). The data were recorded, stored and analyzed offline using PC-based Tida software (Version 5.1, HEKA). All recorded neurons ( $n=25 ; 17$ excitatory and 8 inhibitory) were characterized in terms of their passive as well as active intrinsic electrophysiological properties (Table 1). The electrophysiological data were not corrected for a junction potential of ca. $-10 \mathrm{mV}$. Due to insufficient labeling either of the recorded or the immunostained cells, only a subset of these 25 recorded neurons could be analyzed morphologically (see below).

Slices containing biocytin-filled cells were fixed $12-24 \mathrm{~h}$ in $4 \%$ paraformaldehyde in $0.1 \mathrm{M}$ phosphate buffer (PB, $\mathrm{pH} 7.4)$ at $4^{\circ} \mathrm{C}$. They were then rinsed with $\mathrm{PB}$ several times including an intermediate step with $1 \%$ $\mathrm{H}_{2} \mathrm{O}_{2}$ (in $\mathrm{PB}$ ) to block endogenous peroxidase activity. For confocal analysis, the slices were cryoprotected (25\% saccharose, $10 \%$ glycerol in $0.01 \mathrm{M} \mathrm{PB}$ ) for $1 \mathrm{~h}$ and re-sliced on a freezing microtome (Leica, Bensheim, Germany) at $100 \mu \mathrm{m}$. For correlated light and electron microscopy, they were incubated in the same cryoprotectant, then freeze-thawed three times over liquid nitrogen and finally re-sliced on a vibratome (Leica, Bensheim, Germany).

Immunofluorescence and confocal analysis

Several rinses with $0.1 \mathrm{M} \mathrm{PB}(4 \times 30 \mathrm{~min})$ and $0.05 \mathrm{M}$ TRIS-buffered saline (TBS; $2 \times 15 \mathrm{~min}$ ) as well as TBS with $0.5 \%$ Triton X-100 added (TBST; $2 \times 15 \mathrm{~min}$ ) both at $\mathrm{pH} 7.6$ were performed. Between all subsequent steps, tissue was rinsed with TBST $(4 \times 15 \mathrm{~min})$ unless otherwise noted. As a first step, a pre-incubation of $45 \mathrm{~min}$ in $10 \%$ normal goat serum (Vector, Burlingame, CA, USA) diluted in TBST was performed. As a second step, the tissue was exposed to the primary antibody against PV (raised in mouse; 1:20,000; Sigma clone PA-235, Taufkirchen, Germany), diluted with TBST. The immunoreaction lasted for $60 \mathrm{~h}\left(\right.$ at $\left.6^{\circ} \mathrm{C}\right)$, under gentle agitation. As a third step, incubation of a mixture of streptavidincoupled Alexa 488 (1:200; Molecular Probes, Leiden, The Netherlands) and horse anti-mouse serum tagged with Cy3 (1:400; Dianova, Hamburg, Germany) for $6 \mathrm{~h}$ at room temperature followed. The sections were then rinsed in TBST and TBS $(2 \times 15 \mathrm{~min}$ each $)$. Subsequently, the slices were mounted on glass slides and coverslipped with Vectashield (Vector, Burlingame, CA, USA).

Immunocytochemical controls only included a replacement of the primary antiserum by appropriately diluted normal serum, since the specificity of the antisera was

Table 1 Electrophysiological properties of layer IV neurons

\begin{tabular}{|c|c|c|c|c|}
\hline & \multicolumn{2}{|c|}{ Spiny neurons $(n=17)$} & Basket cells $(n=5)$ & Bitufted cells $(n=4)$ \\
\hline \multicolumn{5}{|l|}{ Passive intrinsic properties } \\
\hline$V_{\mathrm{rmp}}(\mathrm{mV})$ & $-64.2 \pm 2.6$ & $-66.2 \pm 4.9$ & $-65.4 \pm 4.6$ & $-61.8 \pm 2.4$ \\
\hline$R_{\mathrm{m}}(\mathrm{M} \Omega)$ & $237.2 \pm 110.0$ & $212.4 \pm 65.2$ & $151.2 \pm 115.8$ & $110.5 \pm 56.4$ \\
\hline$\tau(\mathrm{ms})$ & $23.2 \pm 7.0$ & $22.6 \pm 6.7$ & $16.0 \pm 8.3$ & $11.7 \pm 4.6$ \\
\hline Active intrinsic properties & $\operatorname{RS}(n=6)$ & $\mathrm{IB}(n=11)$ & FS & RSNP \\
\hline AP threshold (mV) & $-42.5 \pm 3.4$ & $-41.2 \pm 4.5$ & $-44.8 \pm 3.3$ & $-43.8 \pm 2.9$ \\
\hline First AP amplitude (mV) & $65.8 \pm 13.4$ & $60.8 \pm 13.1$ & $68.4 \pm 12.8$ & $65.8 \pm 3.8$ \\
\hline Ratio first/second AP amplitude & $1.02 \pm 0.04^{\mathrm{a}, * *}$ & $1.27 \pm 0.07$ & $1.01 \pm 0.03^{\mathrm{b}, *}$ & $1.1 \pm 0.06$ \\
\hline First-ISI (ms) & $22.8 \pm 12.1^{\mathrm{a}, *}$ & $5.2 \pm 1.0$ & $10.0 \pm 3.8$ & $12.8 \pm 6.0$ \\
\hline Second-ISI (ms) & $59.3 \pm 22.5^{\mathrm{a}, *}$ & $27.6 \pm 18.7$ & $10.6 \pm 3.3^{\mathrm{b}, *}$ & $19.3 \pm 1.3$ \\
\hline Ratio first/second AHP amplitude & $0.57 \pm 0.37$ & $0.74 \pm 0.19$ & $0.9 \pm 0.4^{\mathrm{b}, * *}$ & $1.6 \pm 0.2$ \\
\hline
\end{tabular}

Active intrinsic properties were determined by applying suprathreshold depolarizing current injection at $V_{\text {rmp }}$ eliciting five to ten APs; data are mean $\pm \mathrm{SD}$

$I B$ intrinsically burst spiking, $R S$ regular-spiking, $F S$ fast-spiking, $R S N P$ regular-spiking non-pyramidal, $A P$ action potential, $I S I$ inter-spike interval, $A H P$ hyperpolarizing after-potential

$* P<0.05, * * P<0.01$

a Significant differences between RS and IB cells

b Significant differences between basket and bitufted cells 
extensively tested and approved by the manufacturers. This procedure always resulted in the absence of any staining.

As a backlash for the whole study, the parvalbuminimmunoreaction stopped working reliably after the switch from blind patching in an interface chamber to patching visually identified neurons in a submerged slice chamber. Since inhibitory interneurons are relatively rare, they cannot be recorded with blind patch-techniques in a controlled manner. However, since in material from the submerged slice chamber the immunoreactions were of unacceptable quality (neuropil staining only but no somata), we had to accept the low numbers of inhibitory interneurons in the present study.

The fluorescently labeled sections were examined at a confocal microscope (TCS SP2-AOBS; Leica Microsystems, Mannheim, Germany) equipped with a $40 \times$ oil-immersion objective $(\mathrm{NA}=1.0)$. The region covered by the intracellularly filled neurons was entirely scanned at high resolution by automatically acquiring multiple image stacks with the Arivis Browser (Arivis Multiple Image Tools GmbH, Rostock, Germany). A maximum-intensity projection was calculated for each image stack after scanning and stored together with the original data. For evaluation, however, individual focal planes of the two-channel scans were analyzed with respect to visible contacts between the axon of the filled neuron and the immunohistochemically labeled PV target cells. As a light microscopic contact, a presynaptic bouton was only counted when it was visible over two consecutive thin optical sections and when it was in direct apposition with the target structure without any intervening black pixels. In a separate set of experiments, the identity of these contacts or close spatial appositions as synapses was further verified by correlated light and electron microscopy.

\section{Correlated light and electron microscopy}

This technique has been previously described as well (Staiger et al. 2002; Helmstaedter et al. 2008). Briefly, the ABC method was used to permanently stain biocytin (brown; 3,3'-diaminobenzidine, Sigma) and parvalbumin (blue; Vector SG). Then, the sections were dehydrated in an ascending series of ethanol and embedded in Durcupan ACM (Fluka, Buchs, Switzerland). Finally, selected layer IV neurons ( $n=6$; three spiny stellate and three aspiny basket cells) were re-embedded, trimmed, serially cut ultrathin (Leica UCT, Vienna, Austria), mounted on Formvar-coated single-slot copper grids and examined at the electron microscope (AB-912; LEO, Oberkochen, Germany), to determine the synaptic nature of light microscopically identified contacts.
Quantification and statistics

The boutons of the axon of all well-filled neurons $(n=10$ spiny neurons, $n=4$ aspiny or sparsely spiny interneurons) and all PV-ir neurons contained within this "axonal sphere" (see below) in layer IV as well as the contacts on these putative target cells were plotted (Supplementary Figure 1). Since we measured that on average the stained length of dendrites of PV-ir neurons in layer IV was around $120 \mu \mathrm{m}$, we defined this as the radius of a generic "axonal sphere" of the filled neurons within which a putative synaptic contact could possibly be identified in the present material. These analyses were made with the help of Neurolucida Confocal (MBF-Bioscience Europe, Magdeburg, Germany) and were quantitatively evaluated with Neuroexplorer (MBF-Bioscience). Data are presented as mean \pm SD. Because of the low yield of suitable preparations in this technically demanding study for light versus light and electron microscopic analyses, a statistical comparison of the data was not possible.

\section{Preparation of figures}

Figures were composed and lettered in Illustrator CS2 (Adobe) from micrographs which have previously been modified with Photoshop CS2 (Adobe) to achieve optimal brightness, contrast and color appearance. In some cases sharpness was also increased.

\section{Results}

This first, light microscopic part of the study is based on a population of 14 layer IV neurons of rat barrel cortex ( $n=10$ spiny neurons, two basket and two bitufted, putative dendrite-targeting, interneurons) which have been successfully filled with biocytin. Altogether, their axonal arbors in layer IV possessed 21615 boutons, from which 1831 contacted parvalbumin-immunoreactive target structures. Due to our strict criteria for the definition of a contact, this proportion of $8.5 \%$ of all boutons targeting PV-ir structures might well represent an underestimation of the actual numbers. The 1831 contacts were distributed on somata $(13.7 \%, n=250)$, proximal dendrites which could be traced back to a parent soma $(9.4 \%, n=173)$ and dendrites which could not be traced back to the parent soma ("neuropil contacts"; $76.9 \%, n=1,408$ ) and therefore could not be assigned as with certainty to layer IV neurons. The latter will not be considered further. The axonal sphere within layer IV-barrels (septa contained very few axonal branches which were not considered except for the single bitufted neuron whose soma was also located 

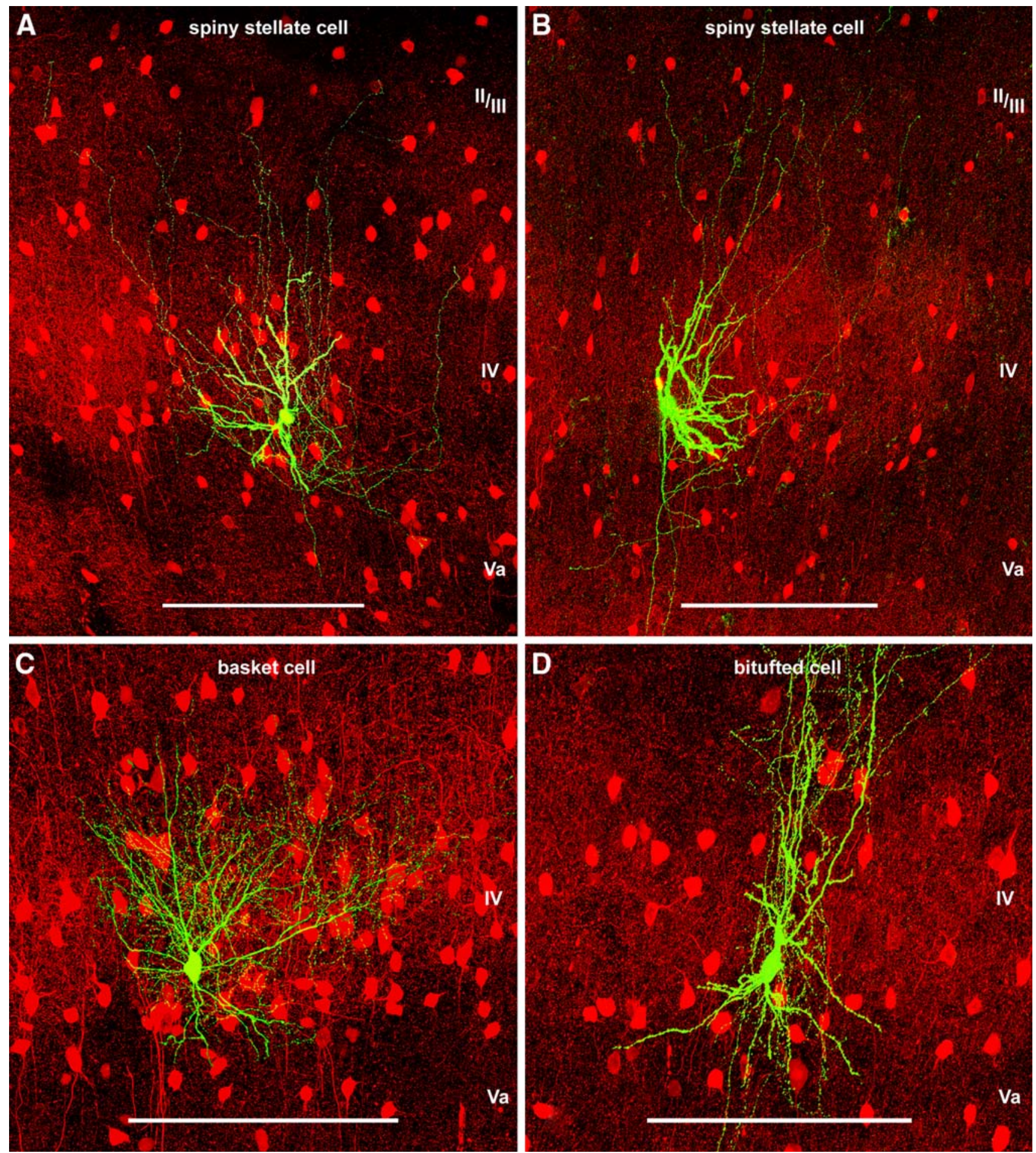

Fig. 1 Confocal imaging of electrophysiologically characterized and biocytin-labeled "presynaptic" neurons (green) and parvalbuminimmunoreactive interneurons (red) in rat barrel cortex displayed as maximum-intensity projections. a High-resolution micrograph showing a typical spiny stellate neuron with a symmetric dendritic tree confined to layer IV and a dense local axonal arbor which further extends mainly to supragranular layers II/III. Note the relatively small barrel reflected by the dense cellular and neuropil staining of PV into which the biocytin-labeled neuron is integrated. b Asymmetric spiny

stellate neuron localized to the side a barrel which is clearly demarcated by the PV-immunoreactivity. c Multipolar interneuron (smooth stellate cell) with a highly dense local axonal arbor suggestive for a basket cells. d Bitufted interneuron (sparsely spiny cell) in a layer IV septum showing a highly restricted, vertically oriented axonal arbor. All images are maximum-intensity projections of z-stacks. Roman numerals indicate cortical layers. Scale bars a-d $250 \mu \mathrm{m}$ 
there) of the filled neurons contained a total of $1091 \mathrm{PV}$-ir neurons from which $150(15 \%)$ received contacts.

Since there are cell type-specific differences in the connectivity patterns of the different classes of (inter)neurons, being excitatory (spiny stellate cell, star pyramidal cells; (Feldmeyer et al. 1999; Staiger et al. 2004)) or inhibitory [basket cells, bitufted cells (Gibson et al. 1999; Markram et al. 2004)], they will be described separately.

Morphological and electrophysiological characterization of spiny neurons presynaptic to parvalbumin-containing interneurons

This analysis is based on ten recorded and filled spiny neurons. The properties and classification of layer IV spiny neurons have been described in detail in our previous papers (Schubert et al. 2003; Staiger et al. 2004). Among the spiny neurons which were used for analysis, eight were classified as spiny stellate cells and two as star pyramidal neurons. Among neurons that were excluded from further analysis was the only true pyramidal cell of our sample. The ten analyzed cells consisted of five symmetric (Fig. 1a) and three asymmetric (Fig. 1b) spiny stellate cells, as well as two star pyramidal cells (not shown) which clearly possessed an apical dendrite extending into the supragranular layers (Staiger et al. 2004). In agreement with the studies mentioned above, the action potential firing pattern was either regular-spiking (RS; $n=4$; Fig. 2a) or intrinsically bursting (IB; $n=6$; Fig. 2 b). It has to be noted that the latter population was of the "weak burster" type which fires an initial doublet followed by single spikes. A summary of the passive and active electrophysiological properties of the entire set of spiny neurons used in this study ( $n=17$ ) is given in Table 1 . The firing type of the respective mapped and analyzed neurons can be found in Table 2 .

Morphological and electrophysiological

characterizations of spiny or sparsely spiny neurons presynaptic to parvalbumin-containing interneurons

The properties of these neurons were well in accordance with several published papers [cf. (Kawaguchi 1995; Cauli et al. 1997)]. In our set of data both neurons with an aspiny multipolar dendritic tree (Fig. 1c) and a clear fast-spiking (FS; according to Petilla terminology: continuous fast spiking) action potential discharge pattern upon injection of depolarizing current (Fig. 2c; Table 1) showed a local barrel-restricted axonal arbor which formed multiple perisomatic boutons (Figs. 3c, d). As it is typical for this electrophysiological class, FS neurons elicited non-adapting trains of single action potentials with prominent, fast after-hyperpolarizations (AHP). In consequence, these neurons were classified as fast-spiking basket cells. Such basket cells dominate the population of inhibitory
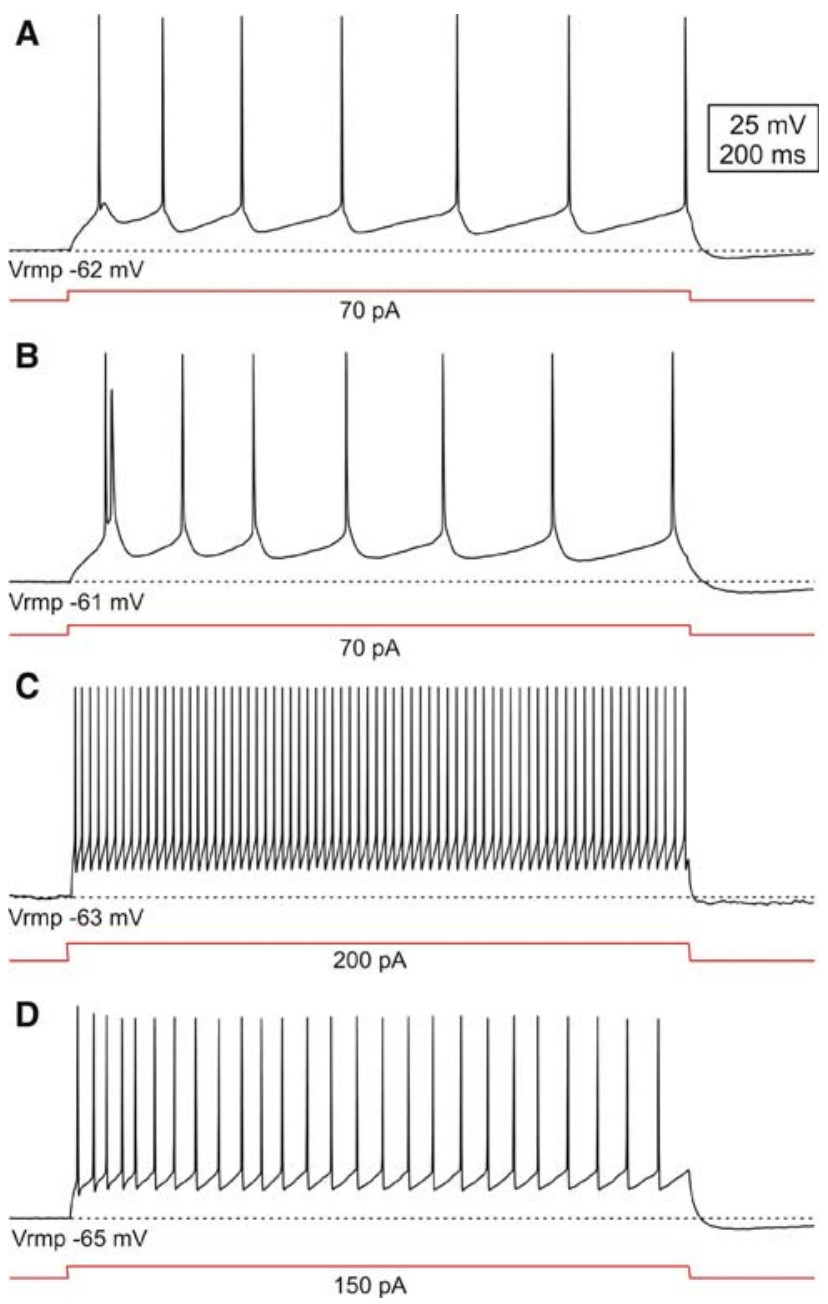

Fig. 2 Action potential firing patterns of layer IV neurons upon current injection at resting membrane potential $\left(V_{\text {rmp }}\right)$. a Regularspiking neuron with depolarizing after potential. b Intrinsically burstspiking cell. c Fast-spiking neuron. d Regular-spiking non-pyramidal cell

interneurons in the barrel compartment and were the prime goal of our study on the basis of their established functional importance (Tamas et al. 2000; Gabernet et al. 2005; Cruikshank et al. 2007). For a second class of neurons the dendritic tree was formed by sparsely spiny dendrites originating from the soma in a bitufted configuration (Fig. 1d). In addition, an axonal arbor which was primarily oriented vertically and thus possessed a substantial translaminar component was found (Fig. 1d). These two neurons displayed a RS action potential discharge pattern showing features typical of non-pyramidal cells (RSNP; according to Petilla terminology: continuously adapting firing pattern), which are that the initial action potential displays a larger amplitude and a more negative AHP than the subsequent action potentials (Fig. 2d). These bitufted cells are probably equivalent to the low-threshold spiking cells which have been characterized as a second major 
Table 2 Connectional properties of individual layer IV neurons with putative PV-ir target structures

\begin{tabular}{|c|c|c|c|c|c|c|c|c|c|c|}
\hline Cell-ID & Type & $\begin{array}{l}\text { Firing } \\
\text { pattern }\end{array}$ & $\begin{array}{l}\text { Bouton } \\
\text { number }\end{array}$ & $\begin{array}{l}\text { PV-ir neurons } \\
\text { in axonal sphere }\end{array}$ & $\begin{array}{l}\text { PV-ir target } \\
\text { neurons }(\%)\end{array}$ & $\begin{array}{l}\text { Somatic } \\
\text { contacts }\end{array}$ & $\begin{array}{l}\text { Dendritic } \\
\text { contacts/ }\end{array}$ & $\begin{array}{l}\text { Neuropil } \\
\text { contacts }\end{array}$ & $\begin{array}{l}\text { Highest number } \\
\text { of somatic } \\
\text { contacts }\end{array}$ & $\begin{array}{l}\text { Highest number } \\
\text { of dendritic } \\
\text { contacts }\end{array}$ \\
\hline IF300300Z2 & SS & IB & 1042 & 54 & $4(7)$ & 3 & 5 & 77 & 3 & 4 \\
\hline IF040500Z1 & SS & IB & 1321 & 61 & $4(7)$ & 5 & 1 & 75 & 2 & 1 \\
\hline IF030400Z2 & SS & IB & 1484 & 101 & $11(11)$ & 6 & 12 & 120 & 3 & 3 \\
\hline DS1_290702 & SS & IB & 1218 & 65 & $4(6)$ & 2 & 5 & 42 & 1 & 2 \\
\hline IF270400Z1 & SP & IB & 1556 & 179 & $20(11)$ & 28 & 10 & 105 & 2 & 3 \\
\hline IF040500Z2 & SP & IB & 1024 & 116 & $8(7)$ & 9 & 4 & 49 & 2 & 1 \\
\hline DS2_071002 & SS & $\mathrm{RS}$ & 907 & 83 & $14(17)$ & 19 & 23 & 32 & 3 & 5 \\
\hline DS1_310702 & SS & $\mathrm{RS}$ & 987 & 114 & $6(5)$ & 10 & 10 & 46 & 4 & 5 \\
\hline DS3_290702 & SS & RS & 806 & 56 & $3(5)$ & 4 & 3 & 26 & 3 & 1 \\
\hline DS5_081002 & SS & RS & 586 & 20 & $3(15)$ & 1 & 6 & 10 & 1 & 5 \\
\hline IF310300Z2 & $\mathrm{BC}$ & FS & 5467 & 100 & $32(32)$ & 80 & 33 & 435 & 10 & 4 \\
\hline DS5_091002 & $\mathrm{BC}$ & FS & 2829 & 48 & $28(58)$ & 59 & 41 & 247 & 8 & 5 \\
\hline DS4_091002 & BIT & RSNP & 1044 & 23 & $3(13)$ & 2 & 4 & 73 & 1 & 3 \\
\hline DS6_091002 & BITsep & RSNP & 861 & 25 & $3(12)$ & 0 & 7 & 28 & 0 & 3 \\
\hline
\end{tabular}

Neuronal type: $S S$ spiny stellate cell, $S P$ star pyramidal cell, $B C$ basket cell, BIT bitufted cell, sep septal location. Firing pattern: $R S$ regularspiking, $I B$ intrinsically burst spiking, $F S$ fast-spiking, $R S N P$ regular-spiking non-pyramidal. Bouton number total number of mapped boutons of the respective neuron within a layer IV barrel. $P V$-ir target neurons number of contacted neurons; in parentheses, actual percentage with respect to all neurons present in the axonal sphere. Somatic contacts sum of all contacts on the somata of PV-ir target neurons. Dendritic contacts sum of all contacts on identified dendrites of PV-ir target neurons. Neuropil contacts sum of all contacts on unidentified PV-ir dendrites. Highest number of somatic/dendritic contacts relates to the single most innervated PV-ir neuron

population of inhibitory interneurons (supposedly somatostatin-containing) with many connectional properties different from basket cells (Beierlein et al. 2003). The electrophysiological properties of this study's full set of inhibitory interneurons $(n=9)$ are summarized in Table 1.

Parvalbumin-containing neurons in layer IV of the barrel cortex

The general distribution and morphology of PV-ir somata, dendrites and presynaptic boutons in the barrel cortex was in complete agreement with previous studies of others (Celio 1990; van Brederode et al. 1991) as well as our more recent own ones (Staiger et al. 1997; David et al. 2007). In fact, the great density of large, mostly multipolar neurons with smooth to varicose dendrites and the intensive staining of the neuropil which included numerous pericellular (basket-like) arrangements of presynaptic boutons altogether let the barrels in layer IV become visible (Fig. 1). With the help of these clearly identifiable barrels, this layer IV-compartment was delineated for subsequent analysis.

Mapping of boutons from spiny neurons onto parvalbumin-immunoreactive neurons

This analysis is based on ten recorded and filled spiny neurons (eight spiny stellate and two star pyramidal cells). Interestingly, when grouped according to their firing pattern (six RS, four IB), a statistically significant difference in the absolute number of boutons within L IV and also the number of neuropil contacts was found (Table 2). However, since a slice artifact cannot be excluded for these absolute numbers, this difference is not discussed further. The spiny neurons showed a very rich local axonal plexus (Fig. 1a, b) which contacted $9.1 \pm 4.2 \%$ of all PV-ir neurons (within the "generic" axonal sphere, as defined in Sect. "Materials and methods"). We mapped, on average, $1.06 \pm 0.45$ somatic and $1.18 \pm 0.5$ dendritic contacts on single PV-ir putative target cell. However, single PV-ir somata could receive up to four somatic (e.g., Fig. 3a) or five dendritic (e.g., Fig. 3b) contacts from putative presynaptic boutons of a single layer IV spiny neuron. The largest number of somatic and dendritic boutons on a single PV-ir cell was 7.

Mapping of boutons from aspiny or sparsely spiny neurons onto parvalbumin-immunoreactive neurons

This analysis is based on two fast-spiking basket cells and two RS bitufted (putative dendrite-targeting) neurons.

The basket cells showed an extremely dense axonal arborization (Fig. 1c) which gave rise to boutons contacting $45 \pm 18 \%$ of all PV-ir neurons embedded within this plexus. On average, we found $2.21 \pm 1.48$ somatic and $1.07 \pm 1.24$ dendritic contacts on single PV-ir putative target cells. Here, individual PV-ir somata could receive up 

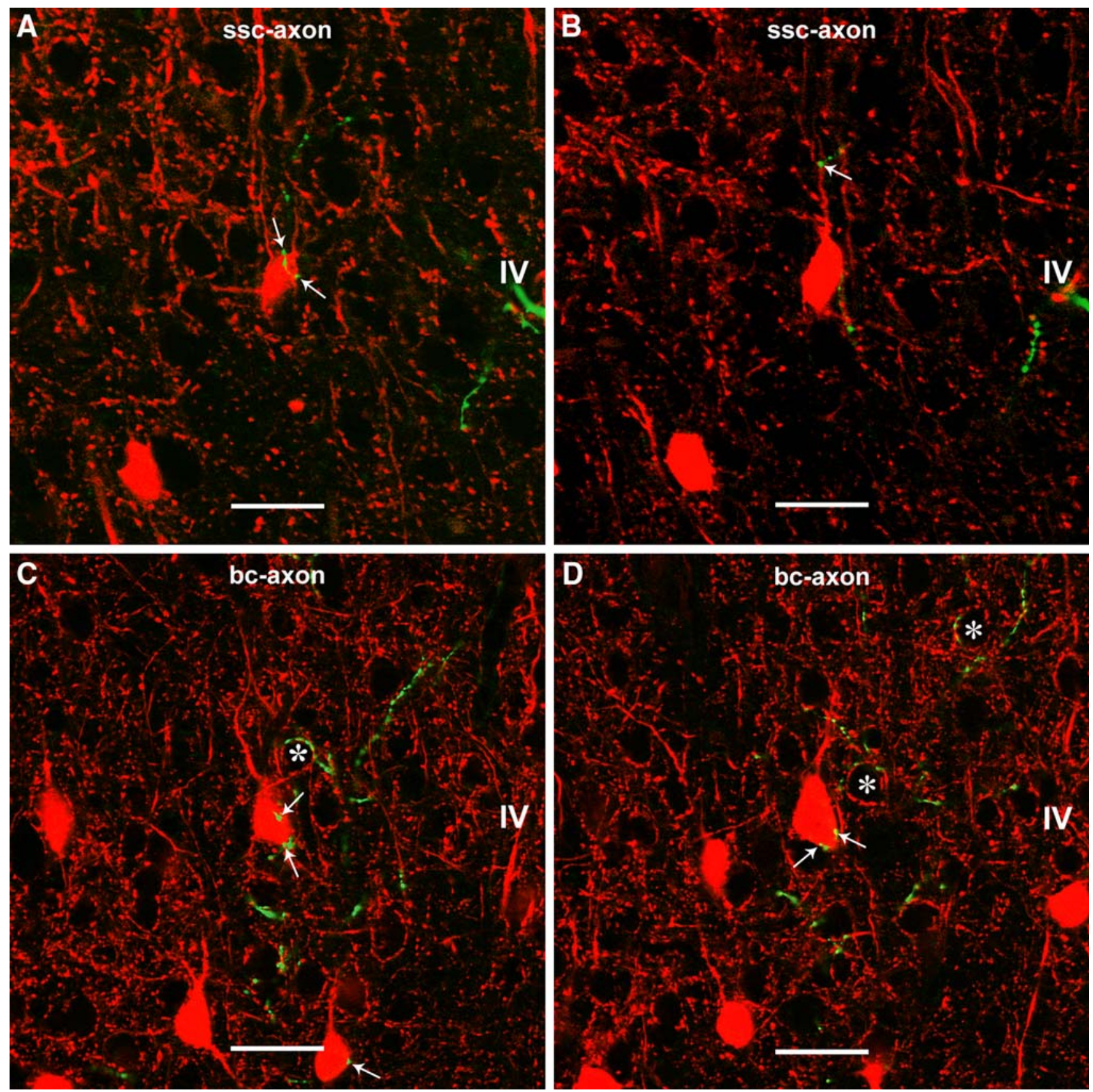

Fig. 3 Single confocal optical sections showing close appositions (arrows) of boutons of putative presynaptic neurons and postsynaptic parvalbumin-immunoreactive cells. Somatic appositions (a) and a dendritic apposition (b) of the spiny stellate neuron shown in Fig. 1a with a multipolar PV cell. c, d Multiple somatic appositions of the

to ten somatic (e.g., Fig. 3c, d) or five dendritic (not shown) contacts from putative presynaptic boutons of a single layer IV-basket cell. The largest number of somatic and dendritic boutons on a single PV-ir cell was 10 .

The bitufted cells displayed a relatively sparse axonal arborization in layer IV (Fig. 1d), one of which was located in the septum. The respective axonal arbor possessed

smooth stellate cell shown in Fig. 1c on a multipolar PV-neuron. Note that some axonal branches of this neuron participate in the formation of pericellular baskets around unlabeled target cells (asterisks) which are "completed" by PV-immunoreactive punctae. Cortical layers are marked by Roman numerals; scale bars $25 \mu \mathrm{m}$

boutons which contacted $12.5 \pm 0.7 \%$ of all PV-ir neurons embedded within this plexus. On average, we found $0.34 \pm 0.28$ somatic and $1.83 \pm 1.06$ dendritic contacts on single PV-ir putative target cell. Here, single PV-ir somata could receive up to one somatic (not shown) or three dendritic (not shown) contacts from putative presynaptic boutons of a single layer IV-basket cell. The largest 
number of somatic and dendritic boutons on a single PV-ir cell was 3 .

\section{Correlated light and electron microscopic analysis}

In this second part of the study, six neurons (three spiny stellate and three aspiny basket cells) were assigned for a proof-in-principle demonstration that the boutons of biocytin-filled neurons apposed to PV-ir target structures in layer IV of rat barrel cortex (as mapped with confocal microscopy) are indeed synapses at the ultrastructural level. In Fig. 4 the typical case of a presynaptic fast-spiking basket cell axon approaching the PV-ir cell body with two very large boutons can be seen (Fig. 4a), the very same constellation being visible in the correlated electron micrograph (Fig. 4b). Interestingly, only one of the boutons $\left(b_{1}\right)$ formed a symmetric synapse on the soma which was visible over several serial sections (Figs. 4c, d). A second synapse was found on a proximal dendrite of the PV-ir cell (Fig. 4e) which was not in focus in Fig. 4a.
The other basket cell showed two somatic and one proximal dendritic synapses on a PV-ir target cell in layer IV. However, in this slice-as was the case for the excitatory spiny neurons - the ultrastructural preservation was poor. In the material sectioned from excitatory neurons, only four somatic synapses on three target neurons were found.

\section{Discussion}

We demonstrate in the present report that rat barrel cortex accomodates in the thalamorecipient layer IV a population of GABAergic interneurons containing parvalbumin which are differentially targeted by cell type-specific circuits originating in the same layer. On one hand, putative excitatory synapses are formed with them by boutons of spiny stellate and star pyramidal cells. These occur in lower numbers on soma or dendrites of roughly $10 \%$ of the available parvalbumin-containing target cells. On the other
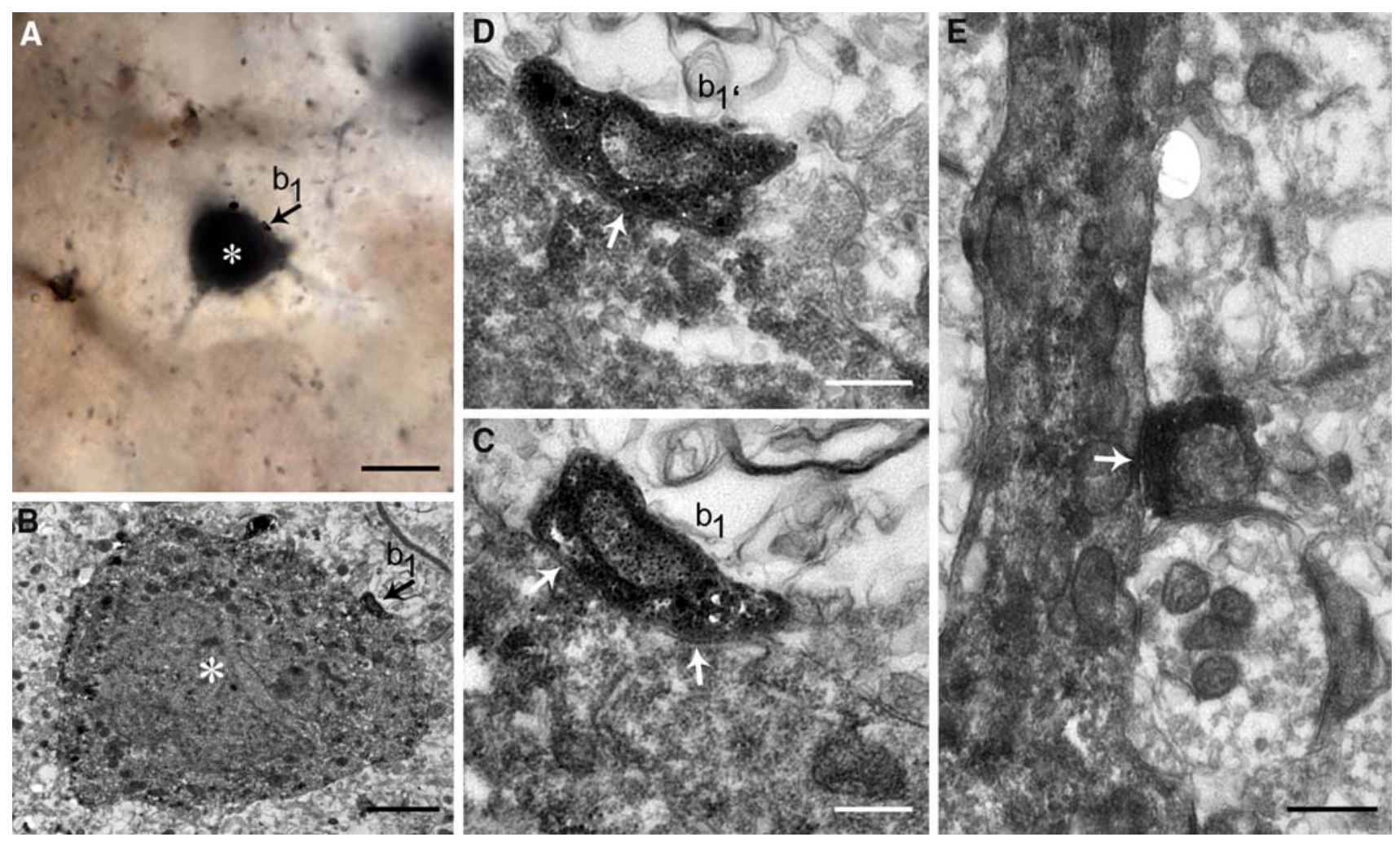

Fig. 4 Correlated light and electron microscopy of synaptic contacts formed by boutons of an electrophysiologically characterized and biocytin-labeled fast-spiking basket cell onto a PV-immunoreactive interneuron in layer IV. a The cell body of the PV-neuron (bluish; asterisk) is contacted by two large boutons (brownish), only one of which $\left(\mathrm{b}_{1}\right.$; arrow) was shown to form a symmetric synapse in the electron microscope. b The correlated electron micrograph of the $\mathrm{PV}$-neuron shows an ultrastructure typical for inhibitory interneurons, i.e., a large eccentric nucleus with an indentation and plenty of mitochondria in the cytoplasm. c The higher magnification of the same ultrathin section as in (b) shows the synaptic cleft (arrows) to be present at the lateral margins of the large mitochondrion-containing bouton $\left(b_{1}\right)$. d A serial follow-up of the boutons $\left(b_{1^{\prime}}\right)$ shows a clearer, centrally located synaptic cleft (arrow). e Another symmetrical synapse (arrow) on a proximal dendrite of the same cell which is not in focus in (a). Scale bars a $10 \mu \mathrm{m}, \mathbf{b} 5 \mu \mathrm{m}, \mathbf{c}-\mathbf{e} 0.5 \mu \mathrm{m}$ 
hand, based on a low number of experimental cases, putative inhibitory synapses are formed with (1) fastspiking basket cells, preferentially by multiple boutons on the soma of approximately $45 \%$ of the target cell population and (2) RS, putative dendrite-targeting interneurons with very few boutons on ca. $12 \%$ of the PV-ir neurons contained within their axonal sphere. This would place the parvalbumin-containing interneurons in a position of the circuitry to (1) effectively function as feedback-inhibition elements as well as to (2) synchronize their own activities by extensive interconnections via chemical synapses [and gap junctions, see (Tamas et al. 2000)]. In conjunction with their known role as feed-forward inhibitors of spiny layer IV neurons upon thalamic action potential discharge (Gabernet et al. 2005; Sun et al. 2006; Inoue and Imoto 2006), the parvalbumin-containing GABAergic neurons are perfectly suited to be a key component of the circuit controlling the spatio-temporal properties, e.g., the receptive field size, of the excitatory spiny neurons, the so-called thalamo-cortical response transformation (Simons and Carvell 1989).

\section{Methodological considerations}

We have used a novel combination of whole-cell recording and biocytin filling of neurons in coronal slices of adolescent rats, together with an immunohistochemical staining of parvalbumin-containing putative target cells [which can be considered to represent mainly fast-spiking basket cells (Kawaguchi 1995; Cauli et al. 1997)]. Our aim was to quantitatively evaluate the occurrence and location of contacts originating from a physiologically and morphologically identified neuron on an entire neurochemically defined population. The advantage of this method, in comparison to paired recordings in layer IV barrel cortex (Beierlein et al. 2003; Gabernet et al. 2005; Sun et al. 2006; Inoue and Imoto 2006), is that it gives a less restricted picture of the abundance and relative frequency of a certain type of connection. This comes, however, with the lack of knowledge of the unitary and dynamic properties of these connections (see references above) and the incomplete staining of the dendrites of the target (parvalbumin) cells, at least when indirect reference data are taken into consideration (Wang et al. 2002; Thomson et al. 2002). Thus, our numbers of dendritic contacts could be underestimated, especially for the "presynaptic" population of spiny neurons and dendrite-targeting cells. However, since we have found a rather proximal location of synapses of on average $77 \pm 44 \mu \mathrm{m}$ distance between spiny stellate cells' presynaptic boutons and GABAergic interneurons' dendrites in layers II/III, the numbers presented here might be valid (Helmstaedter et al. 2008). Since basket cells have a stronger preference for perisomatic contacts (Staiger et al.
1997; Karube et al. 2004), here, the bias is probably much smaller. In conclusion, all numbers reported here in vitro should be considered as minimal values when compared to those obtained in vivo.

Excitatory cortical circuits in layer IV involving parvalbumin neurons

Strong and reliable connections between excitatory layer IV cells have been previously shown (Feldmeyer et al. 1999); however, until recently paired recordings from excitatory and inhibitory neurons in barrels, including a morphological characterization, were not available (Sun et al. 2006). This latter report indicates that uEPSCs of spiny cells in fast-spiking neurons are weaker and less reliable than uIPSCs of fast-spiking neurons in spiny neurons. Although their light microscopic estimation revealed a surprisingly large number of putative contacts, most studies using correlated light and electron microscopy determined that excitatory neurons contact fast-spiking or parvalbumin-containing neurons with a very low number of (electron microscopically verified) synapses, usually in the range of one to three per (unitary) connection (Sik et al. 1993; Buhl et al. 1997; Angulo et al. 1999; Helmstaedter et al. 2008). These numbers are in good agreement with our present study which further shows that the overall density of such connections is in the range of $10 \%$ of the available PV-ir cells. Furthermore, as found in the majority of cases in all layers and species, such excitatory connections onto fast-spiking neurons display short-term depression, also in layer IV of rat barrel cortex (Beierlein et al. 2003; Sun et al. 2006). Thus, it is very likely that a precisely timed and convergent input of multiple excitatory neurons in layer IV is necessary to cause action potential firing in fastspiking parvalbumin neurons, if the latter are decoupled from an effective thalamic input (see below).

A second major excitatory input to layer IV originates from the thalamus. Many different studies have found that fast-spiking basket cells containing parvalbumin are a major target for these afferent projections (Staiger et al. 1996; Porter et al. 2001; Swadlow 2003; Beierlein et al. 2003; Gabernet et al. 2005). It was shown that these neurons in turn convey a fast and efficient thalamus-evoked disynaptic inhibition onto the otherwise monosynaptically excited layer IV spiny neurons, thus creating only a short "window-of-opportunity" for the latter to transmit the sensory information to their target cells. From both, theoretical (Pinto et al. 2003) and in vivo physiological (Bruno and Sakmann 2006) data, it can be concluded that only highly synchronous inputs, putatively signaling salient tactile features detected in the environment, are capable of engaging the target cells of layer IV. Thereby an effective filter is formed for sensory information to enter 
intracortical processing within columnar circuits (Armstrong-James et al. 1992; Beierlein et al. 2002; Gabernet et al. 2005).

Inhibitory cortical circuits in layer IV involving parvalbumin neurons

In recent years, a lot has been learned about the physiological properties of inhibitory-inhibitory interconnections in layer IV (Gibson et al. 1999; Beierlein et al. 2003) whereas knowledge on their morphological connectivity has remained sparse (Tamas et al. 2000). It became obvious that specific subclasses of inhibitory interneurons (i.e., fastspiking and low-threshold spiking cells) not only form electrical and chemical synapses with each other but also receive a strong or a weak thalamic input, respectively (Beierlein et al. 2003). Interestingly, in the supragranular layers of cat visual cortex, a connectivity scheme comparable to the one presented here has been reported (Tamas et al. 1998). These authors showed that basket cells are interconnected by a large number of perisomatic synapses (7-20) whereas double-bouquet cells contact basket cells with only one to four dendritic synapses. Although all double-bouquet cells are considered as dendrite-targeting cells, their action potential firing pattern can show burstspiking, low-threshold spiking or RS properties (Markram et al. 2004). Thus, our RS, dendrite-targeting cells, which formed a rare and low-numbered input on the parvalbumincontaining neurons, are well in accordance with previously published data. As a new aspect, our data suggest that fastspiking basket cells target roughly $45 \%$ of the available parvalbumin-immunoreactive population whereas RS, dendrite-targeting cells do so in only $12 \%$.

\section{Functional considerations}

Are layer IV-PV-containing neurons specialized to control thalamic input? The concept that a distinct subpopulation of inhibitory interneurons may be strategically placed to control a specific excitatory pathway was convincingly developed by Somogyi et al. (1998) in the hippocampus. In the neocortex, evidence for such a constellation has remained elusive, due to the extensively intercalated nature of the intrinsic as well as extrinsic (afferent) pathways. However, a recent study suggested a preferential (though not exclusive) targeting of spines which received thalamic synapses by inhibitory interneurons, indicating that specific relationships of inhibitory interneurons with thalamic pathways may exist in the neocortex (Kubota et al. 2007). In layer IV of sensory cortices the highest numbers of PVir basket cells have been found. The strong and faithful nature of their inhibitory effects on target cells (Freund and Katona 2007) suggests that they are concerned with the fidelity of processing sensory information at the first cortical stage. However, there is some evidence that they are capable of imposing dynamic aspects of information processing on the cortical circuitry as well. Recently, the switching of coincidence detection to integration by layer IV spiny neurons in dependence of the dynamic regulation of FS cells by the frequency of whisker stimulation was demonstrated (Gabernet et al. 2005). That might imply that also the so-called thalamo-cortical response transformation varies in extent in a state-dependent manner (Heiss et al. 2008).

Acknowledgments We thank Mr U. Opfermann-Emmerich for technical assistance and perseverance in the correlated light and electron microscopic analysis. Dr I. Flagmeyer kindly provided biocytin-filled neurons for this study. The study was supported by DFG (Sta 431/5-4; Lu 375/4).

Open Access This article is distributed under the terms of the Creative Commons Attribution Noncommercial License which permits any noncommercial use, distribution, and reproduction in any medium, provided the original author(s) and source are credited.

\section{References}

Ahissar E, Sosnik R, Haidarliu S (2000) Transformation from temporal to rate coding in a somatosensory thalamocortical pathway. Nature 406:302-306

Angulo MC, Staiger JF, Rossier J, Audinat E (1999) Developmental synaptic changes increase the range of integrative capabilities of an identified excitatory neocortical connection. J Neurosci 19:1566-1576

Armstrong-James MA, Fox K, Das-Gupta A (1992) Flow of excitation within rat barrel cortex on striking a single vibrissa. J Neurophysiol 68:1345-1358

Ascoli GA, Alonso-Nanclares L, Anderson SA, Barrionuevo G, Benavides-Piccione R, Burkhalter A, Buzsaki G, Cauli B, DeFelipe J, Fairen A, Feldmeyer D, Fishell G, Fregnac Y, Freund TF, Gardner D, Gardner EP, Goldberg JH, Helmstaedter M, Hestrin S, Karube F, Kisvarday ZF, Lambolez B, Lewis DA, Marin O, Markram H, Munoz A, Packer A, Petersen CCH, Rockland KS, Rossier J, Rudy B, Somogyi P, Staiger JF, Tamas G, Thomson AM, Toledo-Rodriguez M, Wang Y, West DC, Yuste R (2008) Petilla terminology: nomenclature of features of GABAergic interneurons of the cerebral cortex. Nat Rev Neurosci 9:557-568

Beierlein M, Fall CP, Rinzel J, Yuste R (2002) Thalamocortical bursts trigger recurrent activity in neocortical networks: layer 4 as a frequency-dependent gate. J Neurosci 22:9885-9894

Beierlein M, Gibson JR, Connors BW (2003) Two dynamically distinct inhibitory networks in layer 4 of the neocortex. J Neurophysiol 90:2987-3000

Brecht M, Sakmann B (2002) Dynamic representation of whisker deflection by synaptic potentials in spiny stellate and pyramidal cells in the barrels and septa of layer 4 rat somatosensory cortex. J Physiol (Lond) 543:49-70

Bruno RM, Sakmann B (2006) Cortex is driven by weak but synchronously active thalamocortical synapses. Science 312 : 1622-1627 
Buhl EH, Tamas G, Szilagyi T, Stricker C, Paulsen O, Somogyi P (1997) Effect, number and location of synapses made by single pyramidal cells onto aspiny interneurones of cat visual cortex. J Physiol (Lond) 500:689-713

Cauli B, Audinat E, Lambolez B, Angulo MC, Ropert N, Tsuzuki K, Hestrin S, Rossier J (1997) Molecular and physiological diversity of cortical nonpyramidal cells. J Neurosci 17:3894-3906

Celio MR (1986) Parvalbumin in most gamma-aminobutyric acidcontaining neurons of the rat cerebral cortex. Science 231:995-997

Celio MR (1990) Calbindin D-28 k and parvalbumin the rat nervous system. Neuroscience 35:375-475

Cruikshank SJ, Lewis TJ, Connors BW (2007) Synaptic basis for intense thalamocortical activation of feedforward inhibitory cells in neocortex. Nat Neurosci 10:462-468

David C, Schleicher A, Zuschratter W, Staiger JF (2007) The innervation of parvalbumin-containing interneurons by VIPimmunopositive interneurons in the primary somatosensory cortex of the adult rat. Eur J Neurosci 25:2329-2340

Feldmeyer D, Egger V, Lübke J, Sakmann B (1999) Reliable synaptic connections between pairs of excitatory layer 4 neurones within a single 'barrel' of developing rat somatosensory cortex. J Physiol (Lond) 521:169-190

Fox K (2002) Anatomical pathways and molecular mechanisms for plasticity in the barrel cortex. Neuroscience 111:799-814

Freund TF, Katona I (2007) Perisomatic inhibition. Neuron 56:33-42

Gabernet L, Jadhav SP, Feldman DE, Carandini M, Scanziani M (2005) Somatosensory integration controlled by dynamic thalamocortical feed-forward inhibition. Neuron 48:315-327

Gibson JR, Beierlein M, Connors BW (1999) Two networks of electrically coupled inhibitory neurons in neocortex. Nature 402:75-79

Heiss JE, Katz Y, Ganmor E, Lampl I (2008) Shift in the balance between excitation and inhibition during sensory adaptation of S1 neurons. J Neurosci 28:13320-13330

Helmstaedter M, Staiger JF, Sakmann B, Feldmeyer D (2008) Efficient recruitment of layer $2 / 3$ interneurons by layer 4 input in single columns of rat somatosensory cortex. J Neurosci 28:8273-8284

Helmstaedter M, Sakmann B, Feldmeyer D (2009) Neuronal correlates of local, lateral, and translaminar inhibition with reference to cortical columns. Cereb Cortex 19:926-937

Hirsch JA, Martinez LM (2006) Laminar processing in the visual cortical column. Curr Opin Neurobiol 16:377-384

Inda M, DeFelipe J, Munoz A (2009) Morphology and distribution of chandelier cell axon terminals in the mouse cerebral cortex and claustroamygdaloid complex. Cereb Cortex 19:41-54

Inoue T, Imoto K (2006) Feedforward inhibitory connections from multiple thalamic cells to multiple regular-spiking cells in layer 4 of the somatosensory cortex. J Neurophysiol 96:1746-1754

Karagiannis A, Gallopin T, David C, Battaglia D, Geoffroy H, Rossier J, Hillman EMC, Staiger JF, Cauli B (2009) Classification of NPY-expressing neocortical interneurons. J Neurosci 29:3642-3659

Karube F, Kubota Y, Kawaguchi Y (2004) Axon branching and synaptic bouton phenotypes in GABAergic nonpyramidal cell subtypes. J Neurosci 24:2853-2865

Kawaguchi Y (1995) Physiological subgroups of nonpyramidal cells with specific morphological characteristics in layer II/III of rat frontal cortex. J Neurosci 15:2638-2655

Kawaguchi Y, Kubota Y (1997) GABAergic cell subtypes and their synaptic connections in rat frontal cortex. Cereb Cortex 7:476-486

Klausberger T, Somogyi P (2008) Neuronal diversity and temporal dynamics: the unity of hippocampal circuit operations. Science 321:53-57

Kubota Y, Hatada S, Kondo S, Karube F, Kawaguchi Y (2007) Neocortical inhibitory terminals innervate dendritic spines targeted by thalamocortical afferents. J Neurosci 27:1139-1150
Lübke J, Feldmeyer D (2007) Excitatory signal flow and connectivity in a cortical column: focus on barrel cortex. Brain Struct Funct 212:3-17

Markram H, Toledo-Rodriguez M, Wang Y, Gupta A, Silberberg G, Wu CZ (2004) Interneurons of the neocortical inhibitory system. Nat Rev Neurosci 5:793-807

Miller KD, Pinto DJ, Simons DJ (2001) Processing in layer 4 of the neocortical circuit: new insights from visual and somatosensory cortex. Curr Opin Neurobiol 11:488-497

Mountcastle VB (1997) The columnar organization of the neocortex. Brain 120:701-722

Petersen CCH (2007) The functional organization of the barrel cortex. Neuron 56:339-355

Pinto DJ, Hartings JA, Simons DJ (2003) Cortical damping: analysis of thalamocortical response transformations in rodent barrel cortex. Cereb Cortex 13:33-44

Porter JT, Johnson CK, Agmon A (2001) Diverse types of interneurons generate thalamus-evoked feedforward inhibition in the mouse barrel cortex. J Neurosci 21:2699-2710

Ren JQ, Aika Y, Heizmann CW, Kosaka T (1992) Quantitative analysis of neurons and glial cells in the rat somatosensory cortex, with special reference to GABAergic neurons and parvalbumin-containing neurons. Exp Brain Res 92:1-14

Schubert D, Kötter R, Zilles K, Luhmann HJ, Staiger JF (2003) Cell type-specific circuits of cortical layer IV spiny neurons. J Neurosci 23:2961-2970

Schubert D, Kötter R, Staiger JF (2007) Mapping functional connectivity in barrel-related columns reveals layer- and cell type-specific microcircuits. Brain Struct Funct 212:107-119

Sik A, Tamamaki N, Freund TF (1993) Complete axon arborization of a single CA3 pyramidal cell in the rat hippocampus, and its relationship with postsynaptic parvalbumin-containing interneurons. Eur J Neurosci 5:1719-1728

Simons DJ (1978) Response properties of vibrissa units in rat SI somatosensory neocortex. J Neurophysiol 41:798-820

Simons DJ, Carvell GE (1989) Thalamocortical response transformation in the rat vibrissa/barrel system. J Neurophysiol 61:311-330

Somogyi P, Tamas G, Lujan R, Buhl EH (1998) Salient features of synaptic organisation in the cerebral cortex. Brain Res Rev 26:113-135

Staiger JF (2006) Immediate-early gene expression in the barrel cortex. Somatosens Mot Res 23:135-146

Staiger JF, Zilles K, Freund TF (1996) Distribution of GABAergic elements postsynaptic to ventroposteromedial thalamic projections in layer IV of rat barrel cortex. Eur J Neurosci 8:2273-2285

Staiger JF, Freund TF, Zilles K (1997) Interneurons immunoreactive for vasoactive intestinal polypeptide (VIP) are extensively innervated by parvalbumin-containing boutons in rat primary somatosensory cortex. Eur J Neurosci 9:2259-2268

Staiger JF, Schubert D, Zuschratter W, Kötter R, Luhmann HJ, Zilles K (2002) Innervation of interneurons immunoreactive for VIP by intrinsically bursting pyramidal cells and fast-spiking interneurons in infragranular layers of juvenile rat neocortex. Eur J Neurosci 16:11-20

Staiger JF, Flagmeyer I, Schubert D, Zilles K, Kötter R, Luhmann HJ (2004) Functional diversity of layer IV spiny neurons in rat somatosensory cortex: quantitative morphology of electrophysiologically characterized and biocytin labeled cells. Cereb Cortex 14:690-701

Sun QQ, Huguenard JR, Prince DA (2006) Barrel cortex microcircuits: thalamocortical feedforward inhibition in spiny stellate cells is mediated by a small number of fast-spiking interneurons. J Neurosci 26:1219-1230

Swadlow HA (2003) Fast-spike interneurons and feedforward inhibition in awake sensory neocortex. Cereb Cortex 13:25-32 
Tamas G, Somogyi P, Buhl EH (1998) Differentially interconnected networks of GABAergic interneurons in the visual cortex of the cat. J Neurosci 18:4255-4270

Tamas G, Buhl EH, Lorincz A, Somogyi P (2000) Proximally targeted GABAergic synapses and gap junctions synchronize cortical interneurons. Nat Neurosci 3:366-371

Thomson AM, Bannister AP (2003) Interlaminar connections in the neocortex. Cereb Cortex 13:5-14

Thomson AM, West DC, Wang Y, Bannister AP (2002) Synaptic connections and small circuits involving excitatory and inhibitory neurons in layers $2-5$ of adult rat and cat neocortex: triple intracellular recordings and biocytin labelling in vitro. Cereb Cortex 12:936-953

van Brederode JFM, Helliesen MK, Hendrickson AE (1991) Distribution of the calcium-binding proteins parvalbumin and calbindin-D28 $\mathrm{k}$ in the sensorimotor cortex of the rat. Neuroscience 44:157-171

Von Heimendahl M, Itskov PM, Arabzadeh E, Diamond ME (2007) Neuronal activity in rat barrel cortex underlying texture discrimination. PLoS Biol 5:2696-2708
Wang Y, Gupta A, Toledo-Rodriguez M, Wu CZ, Markram H (2002) Anatomical, physiological, molecular and circuit properties of nest basket cells in the developing somatosensory cortex. Cereb Cortex 12:395-410

Welker C (1971) Microelectrode delineation of fine grain somatotopic organization of SmI cerebral neocortex in albino rat. Brain Res 26:259-275

Welker C, Woolsey TA (1974) Structure of layer IV in the somatosensory neocortex of the rat: description and comparison with the mouse. J Comp Neurol 158:437-454

Welker E, Armstrong-James MA, van der Loos H, Kraftsik R (1993) The mode of activation of a barrel column: response properties of single units in the somatosensory cortex of the mouse upon whisker deflection. Eur J Neurosci 5:691-712

Winer JA, Miller LM, Lee CC, Schreiner CE (2005) Auditory thalamocortical transformation: structure and function. Trends Neurosci 28:255-263

Woolsey TA, van der Loos H (1970) The structural organization of layer IV in the somatosensory region (SI) of mouse cerebral cortex. Brain Res 17:205-242 